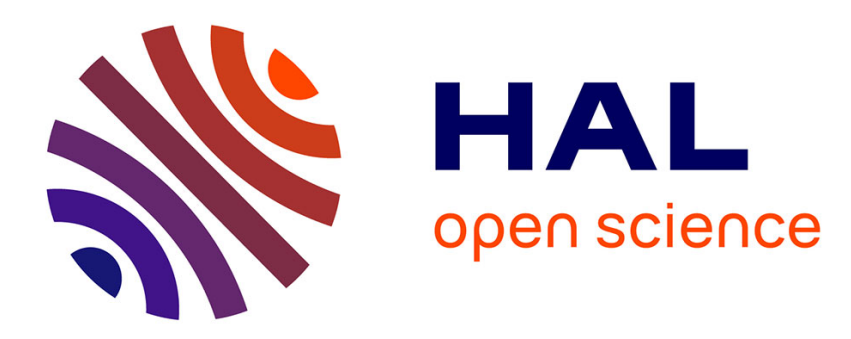

\title{
From madman in the basement to self-sacrificing champion
}

Stacey Abbott

\section{To cite this version:}

Stacey Abbott. From madman in the basement to self-sacrificing champion. European Journal of Cultural Studies, 2005, 8 (3), pp.329-344. 10.1177/1367549405054865 . hal-00571480

\section{HAL Id: hal-00571480 \\ https://hal.science/hal-00571480}

Submitted on 1 Mar 2011

HAL is a multi-disciplinary open access archive for the deposit and dissemination of scientific research documents, whether they are published or not. The documents may come from teaching and research institutions in France or abroad, or from public or private research centers.
L'archive ouverte pluridisciplinaire HAL, est destinée au dépôt et à la diffusion de documents scientifiques de niveau recherche, publiés ou non, émanant des établissements d'enseignement et de recherche français ou étrangers, des laboratoires publics ou privés. 
Copyright (C) 2005 SAGE Publications London, Thousand Oaks cA and New Delhi

Vol 8(3) 329-344: 1367-5494

DOI: $10.1177 / 1367549405054865$ www.sagepublications.com

\title{
From madman in the basement to self-sacrificing champion The multiple faces of Spike
}

Stacey Abbott

Roehampton University

\begin{abstract}
A BSTRACT Towards the end of Season 6 of Buffy the Vampire Slayer, Spike undergoes an identity crisis and leaves Sunnydale in search of a solution.

'Neither a monster nor a man', Spike yearns for reconciliation of his divided self. The answer comes in the form of the return of his soul. This article explores how the return of Spike's soul does not deliver a reconciled Spike but rather one which has been exponentially fragmented. In a show that prides itself on complex character development, Spike undergoes the most dramatic character arc of anyone on the series, taking place in one season in an almost schizophrenic fashion. Through close analysis of mise-en-scène and narrative structure this article demonstrates how each of these personas is presented as distinct and explores how identity in this season is not defined by growth and evolution but rather the recognition that we are each made up of a multitude

of selves.
\end{abstract}

KEYWORDS Angel, Buffy, identity, mise-en-scène, narrative arc, narrative structure, schizophrenia, vampires with souls

The First [in the form of The Mayor] to Spike: 'So what'd you think you'd get your soul back and everything would be jim-dandy? A soul's slipperier then a greased weasel. Why do you think I sold mine? Well, you probably thought that you'd be your own man. And I respect that. But you never will. [Form changes to Drusilla] You'll always be mine. You'll always be in the dark with me.' ('Lessons', 7:1)

Towards the end of Season 6 of Buffy the Vampire Slayer (BtVS), the vampire Spike realises that his situation in Sunnydale is untenable. Because of a computer chip implanted in his brain by the government demon-fighting initiative that prevents him from harming humans, he is 
no longer able to be the vampire that he was. Having attempted to rape Buffy, the woman he loves, similarly Spike realises that he cannot be a man. Suffering an identity crisis, Spike leaves Sunnydale in search of a solution. 'Neither a monster nor a man', Spike yearns for reconciliation of his divided self. The answer comes in the form of the return of his soul. This article will explore how the return of Spike's soul does not deliver a reconciled Spike but rather one which has been exponentially fragmented. In a show that prides itself on complex character development, Spike undergoes the most dramatic character arc of anyone on the series, from madman in the basement to self-sacrificing champion, taking place in one season in an almost schizophrenic fashion.

Through close analysis of narrative structure and mise-en-scène, I will demonstrate how each of these personas is presented as distinct and individual, a mosaic of personalities rather than a coherent character arc. Identity in this season is not defined by growth and evolution but rather the recognition that we are each made up of a multitude of selves. These selves do not lead Spike to further crisis but instead take him one step closer to his final sacrifice.

\section{Vampires with souls}

To understand the impact of the return of Spike's soul, first we must consider his place within a tradition of reluctant and 'ensouled' vampires. The concept of the reluctant vampire originated (if one dares suggest any form of 'original' text) with the television soap opera Dark Shadows (Dan Curtis (producer), 1966-71). The story follows the vampire Barnabas Collins after he is released from the tomb in which his family imprisoned him, to stalk his Maine estate once again. However, he is revealed to be a tortured creature, torn between his human emotions and his vampiric physical needs. The soap-opera narrative fluctuates between storylines on his attempt to find a cure and flashbacks of the tragic circumstances that led to his transformation. Barnabas' conflict is exceeded only by Anne Rice's tormented and self-loathing Louis, the title character of Interview with the Vampire (1976) who, as Janet K. Halfyard has pointed out, has a great deal in common with the vampires of the 'Buffyverse' for he is described in the film version of Rice's novel as 'the vampire with the human soul' (2005: 158). Louis' tragedy is that his new-found vampire senses enable him to see and appreciate the beauty of the human world as never before, simultaneously causing him to become disgusted by his very being which is now designed to destroy all things human. Duality is the essence of the reluctant vampire, torn between conflicting desires. ${ }^{1}$

Within the 'Buffyverse' the reluctant vampire has been transformed into the vampire with a soul, established on BtVS and Angel through the characters of Angel and Darla. One could argue that the introduction of a soul into a vampire is a literalization of the metaphorical humanity of 
vampires such as Barnabas and Louis, which in many ways seems to remove the moral ambiguity of these earlier vampires. They are literally provided a soul, which makes them 'good'. Rhonda Wilcox (2002) has suggested that in BtVS Angel's soul, restored to him through a Gypsy curse, provides a clear-cut distinction between his good and evil sides, while in an interview for the series website, City of Angel (www.cityofangel. com) BtVS-writer David Fury himself has suggested that Angel's journey toward redemption has removed any moral ambiguity from his character (Fury, 2003; Wilcox, 2002). However, this article would argue that the imposition of a soul into the body of a vampire serves to undermine the distinction between monster and human as one dissolves into the other. As has been argued elsewhere (Abbott, 2003), one of the main achievements of the series Angel was to blur the distinction between Angel and his evil alter ego Angelus by recognizing that they are intricately linked together. Angelus' identity may be defined by absence - he is an unrepentant monster because he lacks Angel's soul - but the series goes to great pains to demonstrate that Angel's identity, his strength and power, is defined by the presence of both Angel and Angelus (Abbott, 2003).

The case of Darla is even more interesting and, to my knowledge, has yet to be discussed in detail. One of the most evil of The Master's Brethren of Aurelias, she was chosen and sired by the Master himself. She later transformed the drunken layabout Liam into the diabolically evil Angelus and together they wrought havoc across Europe for 150 years. Darla rejected Angelus after he regained his soul, and 100 years later paid the price for that choice by being killed by Angel in Sunnydale ('Angel', 1:5; 'Becoming: Parts I and II', 2:21 and 2:22; 'The Trial'). Hers is a clear-cut tale of a vampire until this point. However, when resurrected by the evil law firm Wolfram \& Hart on Angel, she became a curious hybrid of her vampire and human selves. Brought back as human with a soul, she has all of the memories of her life as a vampire and still yearns for reconciliation with Angelus, eventually begging Angel to turn her into a vampire again. When he refuses, Wolfram \& Hart bring in Drusilla to do the job in a perversion of 'normal' family lineage ('The Trial'). ${ }^{2}$ Ironically Darla, who was denied salvation and redemption as a human with a soul, finds it as a vampire when she becomes pregnant with Angel's human son. Once again ensouled, this time by the presence of the child within her, she becomes a mix of human and vampire. She feels the goodness of her child's soul and as a result feels genuine love for him, but his presence also causes her to crave the blood of innocent children. She becomes the image of both a nurturing and monstrous mother, reconciling this duality by sacrificing herself to allow the birth of her son ('Lullaby', A3:9).

Spike, the latest in the series' vampires with souls, is a curious entry into this tradition for he possessed this duality before he regained his soul. Claire Fossey (2003) argues that Spike's dual nature, which is made transparent through the implantation of the Initiative's computer chip, is 
actually there from his first appearance on the series and is demonstrated through his love for Drusilla. She argues that

at this point [in Season 2], his humanity functions as what Christopher Golden aptly describes in his novel about Spike and Dru's pre-Sunnydale days as 'a phantom limb': a small presence, as annoying as it is disturbing, which can be easily shrugged off. By Season Six, this minorly troubling and ultimately ignorable phantom limb has grown into a whole other self, a double. (Fossey, 2003)

The chip restrains his monstrous impulses, allowing his humanity room to develop and take stronger hold of his personality. This is exacerbated by his love for Buffy, which again gives him motivation to be good. Rhonda Wilcox argues further that Spike's humanity acts as a complicating agent for Buffy's perception of the world, thus explaining her refusal to believe that he could love her. As she explains:

Spike's is a metaphysically interesting case because of the difficulties it poses ... Spike owns no human soul, yet repeatedly does good; if he can be seen as capable of change, capable of good, capable of love, then he can represent an existentialist definition of good. (Wilcox, 2002)

He confuses Buffy's perception of good and evil, which remains quite clear-cut even as late as Season 6.3 Spike's attempted rape of Buffy in 'Seeing Red' (6:19), aired after Wilcox wrote her article, seems to undermine this reading of his goodness by presenting such an extreme act of violence that it was difficult to imagine accepting that he had changed and recouping him ever again as a hero. However, this scene actually serves to reiterate the duality of the character, acting as a reminder that Spike, like Angel before him, is a vampire who walks a fine line between his monstrous and human desires. For while his actions are monstrous, linking him with the series' misogynist Big Bad, Warren, who also sexually assaulted his ex-girlfriend, Spike acknowledges this in a way that Warren does not. As Jim Smith explains:

In fact he [Spike] ultimately concludes that in order to live with himself after what he has done he must accept that he is a monster, because only a monster could do what he tried to. (2002: 59)

Neither a monster nor a man, Spike looks for resolution.

But if Spike already embodies the series' characteristic moral ambiguity traditionally associated with reluctant or 'ensouled' vampires, then what is the reasoning behind the reintroduction of his soul? One could argue that it is to do just the opposite, by resolving the ambiguity around 332 his character and providing us with a coherent and heroic Spike who is 
able to sacrifice himself for Buffy and humanity at the end of the series. However, this ignores the fragmentation of his personality that characterizes Spike throughout the season, and which will be the focus of the discussion of this article, but it also ignores a fundamental schism within the series itself. Throughout Season 7 of $B t V S$, as well as the final series of Angel, Spike claims that he chose to regain his soul, which separates him from the other 'ensouled' vampires of the series and makes him a truer champion than Angel, who had his soul thrust upon him. This argument assumes that we believe him when he says that he went in search of his soul. As all keen viewers of the series know, the final episodes of Season 6 are far more ambiguous - or in fact not ambiguous at all - as they clearly suggest that Spike went to hell and back again to have the chip removed and be once again what he was: a vampire. After the attempted rape, Spike laments that the chip has confused the natural order of things when he complains:

Everything always used to be so clear. Slayer. Vampire. Vampire kills Slayer. Sucks her dry. Picks his teeth with her bones. It's always been like that. I've tasted the life of two Slayers. But with Buffy ... It isn't supposed to be this way. It's the chip. Steel and wires and silicone. It won't let me be a monster and I can't be a man. I'm nothing. ('Seeing Red', 6:19)

He decides to leave town and as he does, he warns: 'Get nice and comfy, Slayer. I'll be back and when I do ... things are going to change.'

The dialogue in the scene when Spike requests the restoration of his true self is deliberately written so that it can be interpreted either as the removal of the chip or the return of his soul, but Marsters delivers his lines with clear intent. He is playing Spike as a monster, not a hero, made explicit by his repeated references to the chip (he never once mentions his soul) and the aggressive use of the word 'bitch' at the beginning and end of the scene, serving as another link between Spike and Warren, who uses it frequently. This again reinforces the misogynist theme which runs throughout the season and presents Spike's intentions as violent rather than noble:

Spike: Bitch thinks she's better than me. Ever since I got this bleeding chip in my head, things ain't been right. Everything's gone to hell.

Demon: And you want to return to your former self.

Spike: Yeah.

Demon: Look what she's reduced you to.

Spike: It's this chip.

Demon: You were once a legendary dark warrior and you let yourself be castrated. And you have the audacity to crawl in here and demand restoration. ${ }^{4}$

Spike: I'm still a warrior. 
Demon: You're a pathetic excuse for a demon.

Spike: Yeah. I'll show you pathetic. Give me your best shot.

Demon: You would never endure the trials required to grant your request.

Spike: Do your worst. When I win, I want what I came here for. Bitch is going to see a change. ('Villain', 6: 20)

Having endured the trials, Spike demands that the demon 'give me what I want. Make me what I was so Buffy can get what she deserves' ('Grave', 6:22). While again the phrasing of his request can be interpreted either way, the ambiguity is only clear in retrospect after the demon tells him that 'we will return your soul', a line clearly designed to shock audiences. That the intention of this moment was to surprise the audience is supported by the fact that series' producer and writer David Fury (2004) claims in his DVD commentary for this episode that this line was not included in the script so that all involved (and we assume that this means James Marsters himself) believed that Spike's intention was to become a monster again.

This ending therefore creates a tension with the Spike following in Season 7 who claims that his intentions were pure. To ignore this tension and simply believe Spike's story is to forget that this is a television series which, despite the overall coherency of the arc narratives and writing strategies, operates with a range of external imperatives, including the desire to end a season with surprise and shock and the different writing perspectives on narrative, character and theme. For example, David Fury, who has been quite forthright about his own disagreements with certain Spike-related storylines or character arcs despite fan disapproval, explains in an interview with the website City of Angel that a writer can only 'overcome the obstacle of writing a story they can't get behind ... by justify[ing] it to yourself' (Fury, 2003).

The tension between the Spike of Season 6 and the Spike of Season 7 whether or not you believe him - is fundamental to our reading of his character in these final days, for it immediately establishes the existence of two Spikes. Not simply the divided Spike, split between his good and evil side, but rather different Spikes: one a monster intent on embracing his monstrousness; the other 'ensouled', believing that his intentions were good. It is this fragmentation of his identity that comes to define Spike, and to understand the impact of the reintroduction of his soul, first we must examine how and why the narrative structure of Season 7 is built around a series of different Spikes.

\section{Multiple Spikes}

Throughout Season 7 of BtVS, Spike appears, or is discussed, in a range of different personas including the following: mad, tormented, tortured, soulful, seer/truthsayer, bloodhound, stalker/serial killer, vampire, rapist, 
mummy's boy William, William the Bloody, 'Big Bad Spike', the friend, lover and champion. These personas are spread out throughout the season, with some dominating a few episodes while others appear only briefly and overlap with each other. It is the extremity of the differences in Spike's appearance and characterization which suggests that there is more going on than simply the creation of a multifaceted character. Instead, Spike appears almost schizophrenic at times, a fact that is addressed directly within the narrative by his reappearance in Sunnydale as a madman living in the high school basement, seemingly talking to himself. The Scooby Gang describes him repeatedly as crazy and, during brief moments of lucidity, which themselves suggest schizophrenia, he even refers to himself as crazy. In 'Beneath You' (7:2) when Buffy asks Spike, who is ranting incoherently, if he has completely lost his mind, Spike pauses and turns to her and says, 'Well, yes. Where've you been all night?' One episode later in 'Same Time, Same Place' (7:3) Spike insults Xander cleverly in a fantastic moment of clarity that belies his previous musings, by stating: 'I'm insane. What's his excuse?'

The gradual revelation in 'Sleeper' (7:8) and 'Never Leave Me' (7:9) that Spike is the victim of brainwashing by the First, raises the spectre of the psychological fragmentation of 'schizophrenia'. In 'Sleeper' the First appears to Spike as a mirror image of himself, visually splitting Spike in two for the audience's eyes only. The First/Spike encourages him to attack Buffy, to 'take her ... taste her ... make her weak' and be the monster that he should be. The appearance of Spike literally talking to himself visually suggests the idea of personality division. This suggestion is reinforced and made apparent to Buffy in 'Never Leave Me', when she witnesses Spike's transformation from 'tormented Spike' to murderous vampire. Having realized, through his own admission, that Spike has been killing again, Buffy ties him up and attempts to question him. Forced to exit the room briefly to speak to Xander, upon her return Buffy overhears Spike talking and singing through the door. When she re-enters the room, he is alone and seems strange and disconnected from their previous conversation. He then morphs into the vampire and attacks both Buffy and then Andrew. Buffy later tells the gang that at times he seems like another person.

The characters themselves often describe Spike in distinctive ways suggesting an awareness that he is made up of different personas. When he arrives to assist Buffy in 'Beneath You' he is treated by Xander and Dawn as rapist Spike. And as has been mentioned previously, he is regularly described as 'mad' or 'crazy' in the first few episodes of the season. Once suspicions that he may be killing again are aroused in 'Sleeper', he is discussed repeatedly as a stalker or potential serial killer, and noticeably not as a vampire, particularly by Anya who suggests that they should search his room to look for the trophies or souvenirs common among serial killers. In 'Lies My Parents Told Me' (7:17) Robin Wood, preparing to avenge the murder of his mother, tells Spike that he doesn't 'want to kill 
you Spike. I want to kill the monster who took my mother away from me', acknowledging a distinction between the current Spike and his vampiric persona.

When, in 'Never Leave Me', Buffy explains that Spike seemed like a different person before he attacked her and Andrew, Willow asks: 'Like William the Bloody different?' calling to mind yet another image of Spike. The name 'William the Bloody' is used quite often in Season 7 to refer to the murderous vampire that Spike used to be. This is a curious development, as the Scooby Gang have rarely referred to him in this way beyond his first episode, 'School Hard' (2:3), when Professor Giles researched Spike's history as a vampire. While the name 'Spike' had monstrous implications (he impaled his victims with railroad spikes), the character has ceased in their and the audience's eyes to be the murderous vampire that he was and the name has since become the name of a helpless demon, ally, lover and adored character. To consider him once again as a murderous monster, they think of him as having returned to the killer he was by referring to his dark past as William the Bloody (in much the same way that everyone distinguishes Angel from Angelus). However, the name William the Bloody carries with it another image of Spike to which only the audience have been privy, which is William the bloody awful poet ('Fool for Love', 5:7). Therefore, Spike's multiplicity is addressed quite overtly within the narrative and dialogue of the show.

It is through the series' careful manipulation of mise-en-scène that these different personas are evoked and distinguished from one another. The significance of mise-en-scène to the interpretation of character, particularly the series' main vampires, has been established previously through the examples of Angel/Angelus and Drusilla. For example, when Drusilla first arrives in Sunnydale, she is suffering from some form of vampire illness which has weakened her substantially. To evoke this sense of helplessness, she is dressed in lacy or silky white nightgowns, the very image of a Victorian waif ('School Hard'). Once healthy again, she dresses in red and black to evoke a more Gothic sensibility ('Surprise', 2:13). Similarly, when Angel's soul is lost in 'Surprise' and 'Innocence' (2:14), the distinction between Angel and Angelus is made clear to the audience through Angelus' increasing preference for leather trousers, cigarettes and black eyeliner. In addition, the setting itself is used to convey the vampires' differing personalities. The old-world Master is depicted living in a demolished church buried within the earth, while the more modern Spike and Drusilla live in an abandoned factory. When Angelus takes over leadership of the group, they move to a more gothic villa which suits his aesthetic tastes.

Costume and make-up are significant to Spike throughout the series in terms of his consistency of style and look. With the exception of certain flashbacks, which demonstrate different styles for Spike and reflect the changing times in which he lives, from his first arrival through to his 
departure from Sunnydale at the end of Season 6, Spike is generally depicted in a set costume: black leather coat, black jeans, boots, T-shirt, red shirt hanging lose and open, slicked back, bleached blond hair and black fingernail polish (see Amy-Chinn, in this issue, for a more detailed analysis of this look). Spike's image in Season 7, however, undergoes a quite selfconscious deconstruction, as each persona is represented by a different visual look and style. The importance of costuming to signal changes within Spike is prefigured in 'Seeing Red', when Spike leaves his leather coat behind after the attempted rape of Buffy. He leaves Sunnydale, not in the Cadillac established in previous arrivals and departures in 'School Hard', 'Becoming: Part II' and 'Lover's Walk' (3:8), but rather on a motorcycle, and dressed entirely in black. The shedding of his iconic coat prepares the audience for a series of shifting images and representations of Spike which take place throughout the season, indicating changes in his narrative role.

These new 'looks' begin quite shockingly with his first appearance in 'Lessons' (7:1), when Buffy discovers him living in the basement of the new high school. He is almost unrecognizable as Spike for, although still dressed in black, he is now wearing a black shirt which hangs open and loosely around his waist, revealing his scarred chest where he has tried to scratch out his heart/soul. Most significantly, his hair is no longer immaculately bleached and slicked back, but instead he is sporting curly bleached locks that reveal his dark roots. The unkempt look is designed to signify his loss of reason, reinforced by the final shot of him, all in black, sitting in the dark surrounded by such blackness that he is almost lost within its shadows as the First speaks to him in the form of each of the show's annual 'Big Bads'. This visual image reinforces the First/Drusilla's comments to him, stating that he'll always be hers, 'always in the dark with me',

In 'Beneath You', Spike suddenly shows up on Buffy's doorstep, after having been previously presented as mad in the basement, having rebleached and combed his hair and wearing a blue shirt, suggesting that he has regained his sanity and can be of assistance to her. This new look turns out to be a façade, for when he accidentally injures a human he flees in horror at what he has done and retreats to the confines of a local church. When Buffy finds him, he has removed the blue shirt, which he himself describes as a costume that cannot conceal his torment. The blue of the shirt is replaced by the blue filter lighting that surrounds him, no longer concealing his torment but evoking it. Blue is a colour that is repeatedly used in this season, either through lighting or costuming, and in stark contrast to his iconic red shirt serves as a reminder of Spike's ensoulment and resulting torment: but never more evocatively than in this sequence with Buffy. Spike and Buffy, in one of the most beautifully-lit sequences of the series, are surrounded by a chiaroscuro design of blue light and shadow. Spike moves in and out of the dark as he explains in cryptic terms that he regained his soul so that he can never hurt her again, but was 
shocked to face the horrors of his past actions as a vampire. Here, the visual design of the sequence brings together Spike's madness, guilt, torment and repentance, which culminates in the final tragic image of the plight of the ensouled vampire as he drapes over the altar crucifix, begging for solace and comfort as his skin begins to burn.

In contrast to the poignancy of this scene, in 'Same Time, Same Place' (7:3) Spike is still presented as crazy, but now his madness is used to reflect his role as seer rather than as penitent ensouled vampire. In fact, beyond a few exchanges between Buffy and Spike, little reference is made to the previous episode and the magnitude of its revelation and emotional resonance. No longer bathed in blue light or acknowledging this torment, Marsters now plays his scenes as simply crazy. In the high school basement, Willow approaches him to ask about Buffy and Xander as well as a corpse she has found at the school. Their conversation is regularly interrupted by outbursts of non-sequiturs and random poetry. However, it is revealed to the audience, through repetition of events from Buffy and Xander's point of view, that his seemingly insane observations were actually statements he was making to Buffy and Xander, who cannot see Willow. The importance of this sequence is that it places Spike in the role of seer as his seemingly mad ramblings are revealed to the audience to be conversations with those unseen. This foreshadows the revelation to the Scooby Gang, and the confirmation to the audience, that Spike is not madly talking to himself but is in constant conversations with the First. The lack of reference or continuity with the previous episode in terms of Spike's torment also serves as an indicator that Spike's persona is constantly changing and will continue to change throughout the season.

One of the most significant moments for Spike, which takes him down yet another road of multiple Spikes and narratively links costuming with personality changes, is when he reappropriates his leather coat ('Get it Done', $7: 15)$. In this episode, it is revealed that Spike's soul is preventing him from relishing the kill. When defending Anya from a demon sent to kill her, Spike fights back but rather then kill the demon he runs away as soon as it is knocked out. Buffy sees this as a weakness, taunting him: 'If I need someone to get weepy and wailed on, I'll call you.' She needs the 'old Spike' to win this war, and when he is called upon to find and kill another demon in order to save Buffy, he first returns to the high school where he stored the jacket. With the restoration of his coat, we see the return of the much loved Big Bad Spike from previous years who then catches and kills the demon, howling with pleasure and lighting up a cigarette afterwards to mark the occasion, claiming 'a tussle like that is good for the soul'. The coat also acts as a reminder, reinforced by the presence of Robin Wood (principal of the new high school), of the monstrous vampire that Spike was long before his arrival in Sunnydale when he killed Robin's mother, the Slayer Nicky Wood (for the coat originally belonged to Nicky and was taken by Spike as a trophy when she died). 


\section{Vampires and Slayers}

One explanation for Spike's multiplicity is that it is a response to the needs of the plot and the idiosyncrasies of different writers. However, Spike's significance is more than random as in many ways the narrative arc of Season 7 is structured around each of these Spike personas, with a key plot revelation built into the shift between one Spike and another. The relationship between Spike and Buffy also changes as a result of his mosaic of personalities. The first few episodes, in which Spike is mad, see the Scooby Gang reforming and coming to terms with their own past transgressions, increasingly aware that a yet-unnamed threat looms - 'From beneath you it devours'. It is in 'Conversations with Dead People' (7:7) that the season's Big Bad makes its presence known to the gang and part of that revelation, for Buffy and the audience, is the realization that Spike has been killing again. The next two episodes are built around Spike as vampire, stalker and sleeper agent for the Big Bad. It is when Spike is abducted by the Bringers, henchmen of the First, and enters his next phase as tortured victim, that Buffy identifies the Big Bad, having previously encountered the First in 'Amends' (3:10). This realization launches the next section of the series, which is their attempt to understand the First's plan (which is partially explained by the arrival of Giles and the potential Slayers) and fighting the übervamp, unleashed by the First, who is both torturing and guarding Spike. Once rescued, for the most part Spike no longer seems to be mad, tormented, murderous or vampiric (although he 'plays' the vampire for the benefit of the potentials' training). Neither does he seem to be suffering from his quite horrific torture, beyond one reference to some sensitivity around his wounds. He has moved onto his next phase as Buffy's right-hand man, working with her in training of the potentials. He is now Spike the friend and ally.

This is quite a significant development in their relationship and the narrative structure of the season, because we must remember that when Buffy sees Spike in 'Beneath You' she can barely talk to him, as memories of his attack on her come flooding back. She does not welcome him back into the team upon the revelation of the return of his soul, but rather continues to treat him as a mad fool, even using him as a bloodhound in 'Same Time, Same Place', and exhibits a great deal of frustration and irritation with his suffering and torment. It is the movement of Spike's character through each of these different phases, including murdering again, acknowledging his guilt and most significantly his survival of the torture of the First, which enables Buffy to see him as an ally. It is no coincidence that 'Bring on the Night' (7:10), an episode in which Spike is brutally tortured by the übervamp and Buffy suffers one of her worst beatings by the same vampire, ends with Spike unbroken and resilient against the taunts of the First followed by Buffy's emergence from her room, cut and bruised, defiant and determined that she can win. It is at 
this moment that Spike's role as Buffy's shadow and double, previously recognized by both academic writers and fans (Abbott, 2001; Fossey, 2003; Nurss, 2001; Wilcox, 2002), becomes the focus of their relationship throughout the rest of the season. It is following this episode that Buffy is determined to rescue him, describing him as absolutely necessary to the upcoming battle.

This, however, does not mark the end of the multiple Spikes. Instead his schizophrenia climaxes in 'Lies My Parents Told Me', an episode that highlights Spike's fragmentation both narratively and structurally, and demonstrates the significance of Spike's multiplicity to the season. A Freudian's dream episode, the plot deals with Giles' concern about Spike as a potential weapon of the First. He concocts a spell to find the source of the brainwashing. This leads to a series of flashbacks revealing Spike's prevampire and post-vampire relationship with his mother, demonstrating that it is his unreconciled issues with her that lie at the root of his problems. Having made this realization, the trigger is deactivated and Spike emerges at the end of the episode a unified character.

But this episode is more than simply an example of television pop psychology. To begin with, we see more Spikes then ever before. The episode opens in New York City, 1977 as Spike, in full punk-rock vampire mode, engages in his first fight with the Slayer Nicky Wood. The sequence then cuts to the contemporary as Spike, now ally to the Slayer, is engaged in a fight against vampires alongside Buffy and Nicky Wood's son, Robin. This pre-credit teaser establishes both the multiplicity of Spike and the relationship between past and present that will be the focus of the entire episode. In a flashback we are reminded of William the Bloody Awful Poet, as he reads poetry to his mother, and when he sits at her knee and listens to her singing the traditional song 'Early One Morning' (the song that is being used by the First to trigger the transformation of Spike back to his incarnation as a monster), we learn that he was not only a romantic but also a mummy's boy. In a later flashback we see William the newborn vampire, enjoying the sensual and carnal pleasures of his life with Drusilla. Returning to the present day, when he recalls his mother singing (or simply hears the song), he responds, as the First intended, to the trigger by morphing into the monstrous vampire Spike yet again.

What is more significant in this episode is the manner in which these multiple Spikes are presented, for rather than present these personas as individual and distinct, the structure of the episode emphasizes simultaneity. The opening teaser sets up not only certain narrative considerations but also stylistic ones. The move from the past to the present is achieved through a clever sound/lightning mix which suggests a temporal and spatial relationship between the two events. When the young Robin in 1977 New York runs away from his mother to pick up her stake, she calls his name as a flash of lightning overlaps with a cut to a shot of the adult 340 Robin in Sunnydale 2003, as if in response to his mother's call. This way 
of stylistically relating past and present is achieved also through the flashbacks to Spike's past with his mother. Rather than use conventional transitions, i.e. a slow dissolve or fade to black, they are structured to merge the past and present together. The first flashback begins with a flash of bright light over a close-up of Spike as he looks off-screen. The camera tracks around him as it slowly reveals a period setting and a voice is heard reading poetry. The camera stops its tracking movement when it is directly behind the contemporary Spike, looking on at William the poet, reading to his mother. Later in the scene, as William sits at his mother's knee, the camera tracks into an extreme close-up on him until he opens his eyes, and it is as the shot dissolves to the modern Spike that he morphs into the vampire Spike. Here three Spikes are literally merged together through technological means.

This form of mixing past and present, and the different Spikes along with it, continues throughout the episode. It is most significant in the fight between Robin and Spike as a flashback to William's confrontation with his now-vampirized mother, who accuses him of incestuous desire for her, is intercut with the vampire Spike taking a beating from Robin. While he seems to be losing the fight against Robin, it is really the fight against his mother that is weakening him. Only after he tells his mother that he is sorry, repeating the words in the present as well, and stakes her is he able to turn the fight with Robin around and regain his strength and composure. He fights back, but this time not as the vampire Spike but as Spike, pure and simple. He emerges from the fight reconciled, with his usual attitude and vampire pragmatism, as demonstrated by his statement to Robin: 'I don't give a piss about your Mom. She was a Slayer. I was a vampire. That's the way the game is played.' This statement is a return to his lament in 'Seeing Red' about how it used to be. But in this case, he is no longer yearning for that type of clarity but possesses it. When he attacks Robin, he makes it clear that he is not acting under anyone's influence and when he decides to let him live, it is his choice. By confronting and reexperiencing his different selves simultaneously he is forced to accept that they are all a part of him, making him stronger than ever. ${ }^{5}$ When Buffy tells Robin that he was fighting a man who no longer exists, Robin quite rightly tells her, 'Don't delude yourself, that man still exists'. A reconciled Spike is a multiple Spike. But Buffy also rightly points out that 'Spike is the strongest warrior we have. We are going to need him if we are going to come out of this thing alive.' Her words foreshadow the climax of the series when Spike accepts the role of champion by sacrificing himself to save the world ('Chosen', 7:22). Buffy's words connect the moment of his sacrifice with his multiplicity in this episode and suggest that it is the process of embracing his multitude of personas and identities that make him a champion strong enough to close the Hellmouth. To be a vampire with a soul is no longer about moral ambiguity but, as the First in the form of Buffy explains to Spike in 'Lessons', 'It's about power'. 


\section{Conclusion}

To conclude, let us return to the suggestion that Spike is a shadow of Buffy. If this is the case then what is the relationship of Spike's multiplicity with Buffy? The idea that Spike is made up of a multitude of interconnected individual identities contributes to a broader theme of the season. Holden, newly born as a vampire, tells Buffy that he feels 'connected to a powerful all-consuming evil that is going to suck the world in to a fiery oblivion' ('Conversations with Dead People'); the kidnapped Bringer informs Giles under questioning that he is 'part of the great darkness. I am only a fragment of the We' ('Touched', 7:20); and the Guardian of the Scythe explains that she was 'one of many' ('End of Days', 7:21). Yet there is greater emphasis upon Buffy's isolation as the Slayer than ever before. Buffy tells Holden that she is 'not so much connected' ('Conversations with Dead People'); Spike tells her that she is 'The One' ('Touched'); Caleb refers to her as 'the One and Only - Accept No Substitute - Slayer' ('Dirty Girls', 7:18); and Faith and Buffy openly discuss how being a slayer, no matter who surrounds you, means being alone ('End of Days'). In 'Lies My Parents Told Me', Buffy does not recognize Spike's multiplicity in her conversation with Wood, and this is because she has yet to truly recognize her own. However, it is clear to the audience and Robin that at this moment, Buffy herself is part of something even bigger when she echoes Wood's mother's words from the episode's teaser: 'I have a mission. To win this war. To save the world. I don't have time for vendettas ...The mission is what matters.' With the return to the Shadowmen who created the first Slayer and the arrival of the potential Slayers, Season 7 reminds us that she is but one face within a long line of Slayers. The emphasis upon Spike's multiple identities over linear character development, however, prepares the audience for the finale's break with the show's mythology of one Slayer at a time, as Buffy finally accepts that she is 'connected' and sacrifices her 'uniqueness' by sharing her power. From the multiple faces of Spike emerge the multiple faces of the vampire slayer.

\section{Notes}

1. These are not the only reluctant vampires to precede the 'Buffyverse'. Other notable examples would include the vampire police detective working the night shift from the television series Forever Knight (1992 and 1994-6), a key predecessor for Angel, and Blade, the vampire/human hybrid superhero of comic book and film fame.

2. As Darla sired Angelus, who went on to sire Drusilla, this final transformation makes Darla both Drusilla's vampiric daughter and grandmother.

3. Possibly even as late as Season 7. Consider her response to the revelation that Anya, now a vengeance demon again, has murdered a group of university fraternity students because they played a cruel trick on a young woman. When Xander points out that they help their friends when they 
turn evil and start killing people, referring to Willow, Buffy argues that Willow was different as she is human while Anya is a demon with free will. She must die ('Selfless', 7:5).

4. The use of the word 'restoration' at this point is a clue that the end result will be the return of his soul as the spell used to return Angel's soul was the Spell of Restoration ('Becoming: Part I', 2:21).

5. Some might argue that Spike is reconciled at this point because he has confronted and accepted his issues with his mother. While this does explain why the trigger is disabled and he regains his free will, it does not explain why he should emerge having sorted out his identity crisis. The two issues seem unrelated at this point.

\section{References}

Abbott, S. (2001) “"A Little Less Ritual and a Little More Fun": The Modern Vampire', Slayage. The Online Journal of Buffy Studies 3(June). [Available at: www.slayage.tv/essays/slayage3/Abbott.html]

Abbott, S. (2003) 'Walking the Fine Line Between Angel and Angelus', Slayage. The Online Journal of Buffy Studies 9(August). [Available at: www.slayage.tv/ essays/slayage9/Abbott.html]

Fossey, C. (2003) "Never Hurt the Feelings of a Brutal Killer": Spike and the Underground Man', Slayage. The Online Journal of Buffy Studies 8(March). [Available at: www.slayage.tv/essays/slayage8/Fossey.html]

Fury, D. (2003) 'The Sound of Fury, Part I and II', interview in City of Angel: Behind the Scenes. [Accessed 8 July 2004: cityofangel.com/behindTheScenes/ bts3/fury.html]

Fury, D. (2004) DVD commentary for 'Lies My Parents Told Me', Buffy the Vampire Slayer Season 7 . DVD Collection, Region 2, Twentieth Century Fox. Halfyard, J.K. (2005) 'The Dark Avenger: Angel and the Cinematic Superhero', in S. Abbott (ed.) Reading Angel, pp. 149-62. London: I.B. Tauris.

Nurss, D.J. (2001) 'Spike as Shadow', Fists and Fangs. [Available at: http:/ ficbitch.com/fistsandfangs/spikeasshadow.html]

Rice, A. (1976) Interview with the Vampire. London: Futura Books.

Smith, J. (2002) 'Into the Woods ... and Far Away', Starburst Slayer Special 53 : 54-9.

Wilcox, R.V. (2002) "Every Night I Save You": Buffy, Spike, Sex and Redemption', Slayage. The Online Journal of Buffy Studies 5(May). [Available at: www.slayage.tv/slayage/essays/slayage5/wilcox.html]

\section{Biographical note}

Stacey Abbott is a lecturer in film and television studies at Roehampton University, where she teaches courses on textual analysis, world cinema and genre studies. Prior to teaching at Roehampton, she was an education officer for the British Film Institute. She received her PhD at the University of London, where her thesis, "Up-to-Date With a Vengeance": Modern Vampires from Dracula to Blade' was a close examination of the modern vampire film. It was 
through this research that she first became interested in Buffy the Vampire Slayer and Angel. She has since written on both Buffy and Angel for Slayage: The Online International Journal of Buffy Studies and has recently edited an anthology of essays on Angel. She has also written on F.W. Murnau's classic vampire film Nosferatu (1922), the rise of the horror blockbuster in Hollywood cinema and the work of New Zealand horror filmmaker David Blyth. ADDREss: Roehampton University, School of Arts, Film and Television Studies, Digby Stuart College, Roehampton Lane, London, SW15 5P, UK. [email: s.abbott@roehampton.ac.uk] 